\title{
Proximate Composition and Functional Properties of Some New Groundnut Accessions
}

\author{
Khalid Alhassan ${ }^{1}$, Jacob K. Agbenorhevi ${ }^{1, *}$, James Y. Asibuo ${ }^{2}$, Gilbert O. Sampson ${ }^{3}$ \\ ${ }^{1}$ Department of Food Science and Technology, Kwame Nkrumah University of Science and Technology, Kumasi, Ghana \\ ${ }^{2}$ Crops Research Institute, Council for Scientific and Industrial Research, Fumesua-Kumasi, Ghana \\ ${ }^{3}$ Department of Hospitality and Tourism Education, University of Education, Winneba, Kumasi, Ghana \\ *Corresponding author: jkagbenorhevi.cos@knust.edu.gh, jkagbenorhevi@yahoo.com
}

\begin{abstract}
Ten new accessions of groundnut (Arachis hypogea) were oven dried and processed into full fat powdered forms and analysed for the proximate and functional properties using AOAC official methods. The crude protein ranged $20.7-25.3 \%$, crude fat $31-46 \%$, ash $1.2-2.3 \%$, crude fiber $1.4-3.9 \%$, carbohydrate $21-37 \%$ and moisture 4.9-6.8 \%. Energy values of the groundnut accessions were between $525 \mathrm{kcal} / 100 \mathrm{~g}$ and $606 \mathrm{kcal} / 100 \mathrm{~g}$. The ash, moisture, carbohydrate, fat and fiber values of all groundnut accessions proved to be significantly different whereas there was no significant difference amongst the protein values at $\mathrm{p} \leq 0.05$. The bulk density ranged between $0.63 \mathrm{~g} / \mathrm{cm}^{3}$ and $0.88 \mathrm{~g} / \mathrm{cm}^{3}$ whereas water absorption capacities were between $20 \%$ and $30 \%$. Swelling power ranged from $2.98 \mathrm{~g} / \mathrm{g}$ to $4.18 \mathrm{~g} / \mathrm{g}$ and solubility index was between $26.5 \%$ and $57 \%$ with no significant difference at $\mathrm{p}$ $\leq 0.05$. Foaming capacity ranged from $4.0-16.2 \%$ and stability $94-100 \%$. Samples showed a significant difference in terms of bulk density at $p \leq 0.05$. The relatively high protein content of all the accessions as well as their functional properties make them a valuable protein supplement in weaning foods as well as the treatment of protein energy malnutrition cases.
\end{abstract}

Keywords: Arachis hypogea, protein, physicochemical, functional properties

Cite This Article: Khalid Alhassan, Jacob K. Agbenorhevi, James Y. Asibuo, and Gilbert O. Sampson, "Proximate Composition and Functional Properties of Some New Groundnut Accessions." Journal of Food Security, vol. 5, no. 1 (2017): 9-12. doi: 10.12691/jfs-5-1-2.

\section{Introduction}

There have been several improvements relating to different food items in the wake of tackling food insecurity. This has led to an increase in the research to unveil accessions of different desirable qualities. In developing countries such as Ghana, groundnuts (Arachis hypogea) have a significant role in the diet of the population first as a primary protein and a source of reliable cooking oil of high quality [1]. Considering the rapid growth of the world's population in relation to the wide range of products being developed, the aim of agronomic research must not only be the improvement in crop productivity but also nutritional, physicochemical as well as functional properties of the food crop in question. In the case of groundnut this cannot be overemphasized. According to Tshilenge-Lukanda et $a l$. , [2] assessing the genetic diversity of a crop species is a necessary step to its improvement and assists in generating diversified breeding populations.

In Ghana, though groundnut is grown in all the agro-ecologies, the crop is cultivated mainly in the northern sector and is put to many uses including food, feed as well as extraction of oil for cooking, cosmetics and for making detergents. To the agronomist, it is also used in cropping systems as a nitrogen restorer [3]. There has been an increase in groundnut production in Ghana as its commercial value continues to increase with the country targeting international markets. Groundnut production area grew by $47 \%$ between 1999 and 2010, while actual production grew by $69 \%$ over the same period. According to Ministry of Food and Agriculture (MOFA) [4], Ghana had 187k metric tons production surplus, equal to $39 \%$ of total production [5]. This clearly demonstrates Ghana's potential of becoming a groundnut hub as well as being a net exporter of same. Also Ghanaian entrepreneurs can commercialize by-products of groundnut in the hope of mitigating postharvest losses while adding value to the crop. As agronomists develop new accessions, it is important to evaluate and ascertain their nutritional composition to encourage increased cultivation and consumption of the nut by the populace. The uniqueness of functional properties specific to a particular groundnut accession is essential to its incorporation in the ever unending food products that come to the market [6].

To this effect, this research sought to evaluate the proximate composition of the new groundnut accessions and investigate their functional properties.

\section{Materials and Methods}

\subsection{Sample Preparation}

The 10 groundnut accessions were obtained from the Crop Research Institute of the Council for Scientific and 
Industrial Research (CSIR-CRI) at Fumesua-Kumasi, Ashanti Region, Ghana. These are namely: Yenyawoso, GK 7, ICGV 03331, ICGV 99053, ICGV 02171, ICGV 01279, ICGV 01273, ICGV 02184, ICGV 99017, ICGV 99033 accessions. Freshly harvested samples were oven dried in a hot air oven (FS Tupola Plant- Wageningen) at $105^{\circ} \mathrm{C}$ for $4 \mathrm{~h}$. The dried nuts were milled using a hammer mill to flour of $0.2 \mathrm{~mm}$ particle size. The flour was transferred into a zip-locked high density polyethylene bag and stored in a cool and dry place for further analysis.

\subsection{Proximate Composition Determination}

The proximate compositions (moisture, ash, crude protein, crude fat, crude fibre and carbohydrate) of the ackee aril flours were determined using the methods described by the Association of Official Analytical Chemists [7]. Carbohydrate content was determined by difference while percentage nitrogen was determined by the macro-Kjeldahl method and converted to crude protein content by multiplying with factor 6.25 .

\subsection{Functional Properties Determination}

The Swelling Power and Solubility Index determinations of the groundnut powder were carried out based on modifications of the Method of Leach et al. [8] while the water absorption capacity was determined using the method described by Sathe and Salunkhe [9] as modified by Adebowale et al. [10]. Foaming capacity and foaming stability were measured according to the method described by Jitngarmkusol et al. [11]. The bulk density was determined according to the method described by Maninder et al. [12].

\subsection{Statistical Analysis}

The experimental design employed in this study was a Completely Randomized Block Design. Data was reported as averages of triplicate determinations and analyzed using Analysis of Variance (ANOVA). Duncan's multiple range test at 5\% level of significance was applied to determine significant differences among samples. The statistical package used was IBM SPSS Statistics version 20 (IBM Corp, Armonk, NY).

\section{Results and Discussion}

\subsection{Proximate Composition of New Groundnut Accessions}

The crude fat, ash, crude fibre, protein, moisture and energy values of the accessions are presented in Table 1. The carbohydrate content of the groundnut accessions ranged from $21.34 \%$ to $36.90 \%$ with ICGV 99053 recording the lowest while ICGV 03331 gave the highest carbohydrate content. In a similar work conducted by Ayoola and Adeyeye [13], the carbohydrate contents of fresh groundnut samples gave $17.41 \%$, while sun dried and oven roasted (at $105^{\circ} \mathrm{C}$ ) samples gave higher carbohydrate content of $27.19 \%$ and $36.11 \%$, respectively due to the concentration of nutrients after dehydration. These high amounts of carbohydrates in accessions investigated confer on them, significant roles to human health especially in the supply of energy.

The levels of protein in the accessions were relatively high. The least amongst them was ICGV 03331 which gave a protein content of $20.71 \%$ and was significantly different from the other accessions with ICGV0 1279 recording the highest protein content of $25.34 \%$. Generally the protein content recorded for 10 accessions is relatively greater than most pulses also the high protein content is desirable as some functional properties have long been associated with the activities of proteins.

As shown in Table 1, there were significant differences ( $p<0.05)$ among the accessions with respect to crude fat. The fat content ranged from $31.50 \%$ to $45.75 \%$ with GK7 recording the least while ICGV 02171 having the highest. This presupposes that oils from this plant can be extracted and incorporated in to food or feed formulations requiring high levels of fat. In addition, the oil yield can be processed into cosmetics and biofuel.

Table 1. Proximate Composition of New Groundnut Accessions

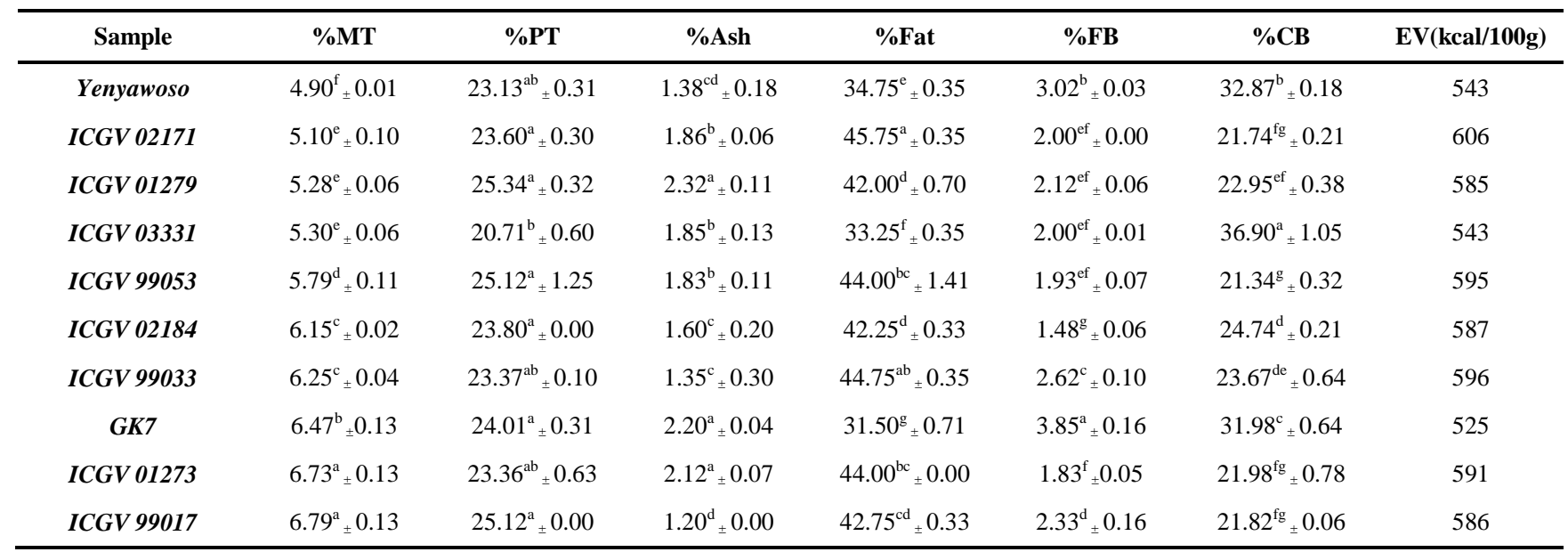

Mean values in the same column followed by different letter ( $\mathrm{s})$ are significantly different at $\mathrm{p} \leq 0.05$. MT: Moisture; PT: Protein; FB: Fiber; CB: Carbohydrate, EV: Energy Value. 
Crude fiber content ranged from $1.4 \%$ to $3.9 \%$. Accession GK 7 recorded the highest crude fiber content, followed by Yenyawoso whilst ICGV 02184 recorded the least of 3.85, 3.02, and 1.48 respectively. These results are close to other varieties of groundnut seeds (Atasie et al., [6]; Ingale and Shrivastava, [14]. The values of crude fibre obtained indicate that the groundnut varieties have the ability to give bulk to foods.

The ash content of the groundnut accessions ICGV 99017 was significantly lower than ICGV 01279 (p < 0.05). The ash content for ICGV 99017 and ICGV 01279 was $1.20 \%$ and $2.32 \%$, respectively. Mineral composition values recorded are close to values obtained by Atasie et al., [6] as well as Gul and Safdar [15].

The moisture content of the accessions ranged from $4.9 \%$ to $6.79 \%$. These values were recorded by Yenyawoso and ICGV 99017 respectively. All accessions proved to be significantly different from each other at $\mathrm{p} \leq 0.05$.

Calorific value was highest in ICGV 02171 with a value of $606 \mathrm{kcal} / 100 \mathrm{~g}$ and lowest in $G K 7$ with a value of $525 \mathrm{kcal} / 100 \mathrm{~g}$. Such values of carbohydrate, protein and fat obtained have been suggested by Eshun et al., [16] that groundnuts could be used to manage protein energy malnutrition. The highest value is slightly above that which was reported by Eshun et al. [16] whilst the least equally fell slightly lower than the least amongst the four cultivars investigated by Eshun et al., [16].

\subsection{Functional Properties}

Foaming capacity in full fat groundnut accessions ranged $4.0-16.2 \%$. Graham and Phillips [17] linked good foaming properties to flexible protein molecules, which decreases surface tension.

The foaming Stability of the samples was very high. Stability values ranged between $94 \%$ and $100 \%$. This suggests the viscoelastic film formed via intermolecular interactions of constituent proteins is so strong that once there is formation of foam, its collapse is very difficult despite the low foaming capacity. As indicated by Adebowale et al., [10], defatting markedly increase the foaming capacity in the flours. Thus a fair balance of fat in the accession could prove to yield high foaming stability cum capacity. The relationships between percentage protein, fat, foaming capacity and stability are shown in Figure 1.

The results obtained as water absorption capacity (20-29\%) for the accessions can be found in Table 2 . There was no significant difference amongst the samples except for ICGV 99053 and GK 7 at $p \leq 0.05$. The values obtained were low as compared to works by Fekria et al., [18]. The main factor that can be attributed to the low nature of WAC is because of the heavy presence of fat within the samples. Literature is replete with data that suggests that WAC of defatted samples tend to be by far higher than those of undefatted samples as the presence of hydrophilic structures in fat restricts water movement. Flours with high WAC have more hydrophilic constituents such as polysaccharides $[18,19]$.

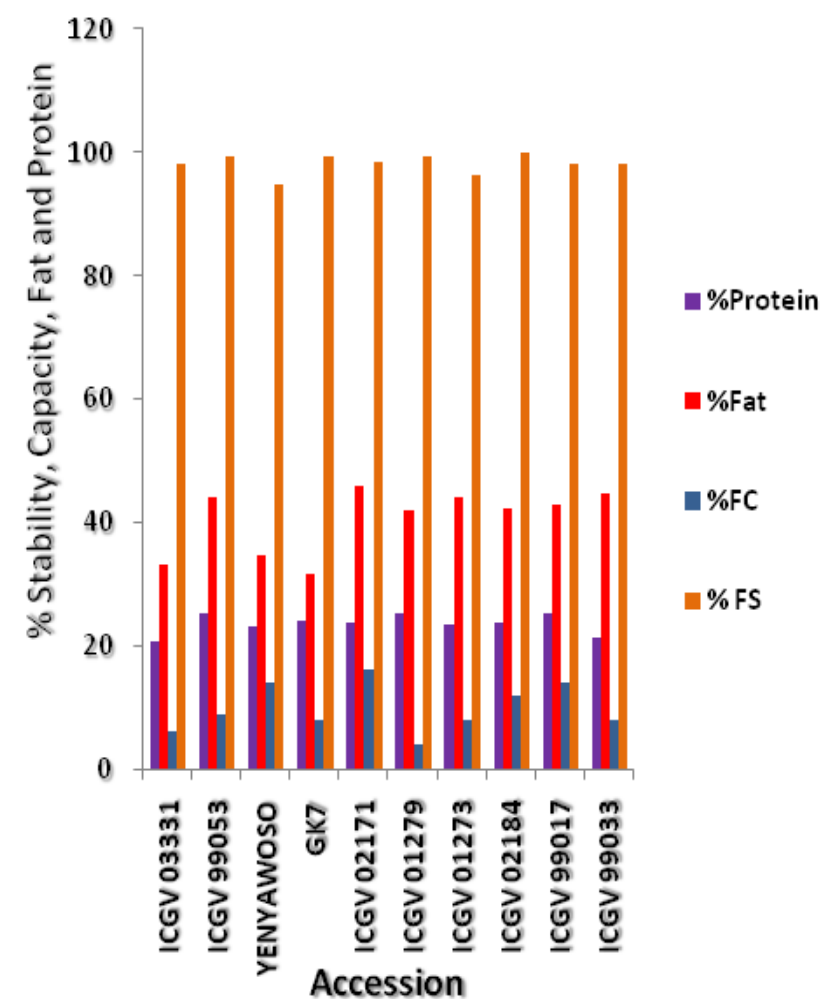

Figure 1. Relationship amongst Percentage Protein, Fat, Foaming Capacity (FC) and Stability (FS)

Table 2. Water Absorption Capacity, Swelling Power, Solubility Index and Bulk Density of New Groundnut Accessions

\begin{tabular}{|c|c|c|c|c|}
\hline Sample & WAC (\%) & $\mathrm{SP}(\mathrm{g} / \mathrm{g})$ & SI (\%) & $\mathrm{BD}\left(\mathrm{g} / \mathrm{cm}^{3}\right)$ \\
\hline Yenyawoso & $25.0_{ \pm}^{\text {abcd }} 0.00$ & $3.72^{\mathrm{abc}} 0.45$ & $38.50^{\mathrm{bc}}{ }_{ \pm} 0.71$ & $0.690^{c}{ }_{ \pm} 0.003$ \\
\hline ICGV 02171 & $25.0_{ \pm}^{\mathrm{abcd}} 0.00$ & $4.14^{\mathrm{a}}{ }_{ \pm} 0.08$ & $38.00_{ \pm 2}^{\mathrm{abc}} 2.83$ & $0.625^{\mathrm{e}}{ }_{ \pm} 0.000$ \\
\hline ICGV 01279 & $25.0_{ \pm}^{\mathrm{abcd}} 0.00$ & $3.08^{\mathrm{bc}}{ }_{ \pm} 0.62$ & $35.00^{\mathrm{bc}}{ }_{ \pm} 1.41$ & $0.725^{\mathrm{b}}{ }_{ \pm} 0.007$ \\
\hline ICGV 03331 & $27.5^{\mathrm{ab}}{ }_{ \pm} 0.40$ & $3.40^{\mathrm{abc}} 0.17$ & $57.00^{\mathrm{a}}{ }_{ \pm} 1.41$ & $0.629^{\mathrm{e}}{ }_{ \pm} 0.005$ \\
\hline ICGV 99053 & $20.5^{\mathrm{d}}{ }_{ \pm} 0.40$ & $4.18_{ \pm}^{\mathrm{c}} 0.71$ & $36.00^{\mathrm{bc}}{ }_{ \pm} 0.00$ & $0.877^{\mathrm{a}}{ }_{ \pm} 0.021$ \\
\hline ICGV 02184 & $24.0_{ \pm}^{\mathrm{bcd}} 0.14$ & $3.38^{\mathrm{c}}{ }_{ \pm} 0.71$ & $34.00^{\mathrm{bc}} 2.83$ & $0.704^{\mathrm{c}}{ }_{ \pm} 0.012$ \\
\hline ICGV 99033 & $22.0^{\mathrm{cd}}{ }_{ \pm} 0.14$ & $2.98_{ \pm}^{\mathrm{c}} 0.03$ & $40.00^{\mathrm{ab}}{ }_{ \pm} 0.00$ & $0.662^{\mathrm{d}}{ }_{ \pm} 0.005$ \\
\hline$G K 7$ & $29.0^{\mathrm{a}}{ }_{ \pm} 0.14$ & $3.80_{ \pm}^{\mathrm{abc}} 0.29$ & $39.50^{\mathrm{ab}}{ }_{ \pm} 2.12$ & $0.658^{\mathrm{d}}{ }_{ \pm} 0.000$ \\
\hline ICGV 01273 & $24.0^{\mathrm{bcd}} 0.40$ & $3.28_{ \pm}^{\mathrm{abc}} 0.06$ & $26.5^{\mathrm{c}}{ }_{ \pm} 2.12$ & $0.685^{\mathrm{c}}{ }_{ \pm} 0.006$ \\
\hline ICGV 99017 & $26.0^{\mathrm{abc}} 0.14$ & $4.12^{\mathrm{ab}}{ }_{ \pm} 0.34$ & $53.50^{\mathrm{ab}}{ }_{ \pm} 2.12$ & $0.694^{\mathrm{c}}{ }_{ \pm} 0.000$ \\
\hline
\end{tabular}

Mean values in the same column followed by the different letter ( $\mathrm{s}$ ) are significantly different at $\mathrm{p} \leq 0.05$. 
An observation made by Ikegwu et al., [20] emphasized a positive correlation between swelling power and starch solubility in pure flours. A similar development was seen in the present study though whole undefatted groundnut accessions were investigated. It can be seen from Table 2 that, generally as the swelling power increased, solubility also increased. Dengate [21] also indicated that with respect to temperature, this is seen as a result of swelling permitting the exudation of amylose. The accessions ICGV 99017 and ICGV 03331, gave swelling power of $4.12 \mathrm{~g} / \mathrm{g}$ and $3.40 \mathrm{~g} / \mathrm{g}$ as well as a high corresponding solubility index of $53.50 \%$, and $57.00 \%$, respectively. ICGV 99033 gave the least swelling power $2.98 \mathrm{~g} / \mathrm{g}$ yet produced a higher solubility index of $40.0 \%$ when compared to ICGV01273 of 3.28 $\mathrm{g} / \mathrm{g}$ swelling power yet gave a solubility index of $26.5 \%$.

The bulk density values obtained were from $0.63 \mathrm{~g} / \mathrm{cm}^{3}$ to $0.88 \mathrm{~g} / \mathrm{cm}^{3}$ indicating a significant difference between the values at $\mathrm{p} \leq 0.05$. From work conducted by Adebowale et al. [10] values obtained ranged from 0.42 to $0.61 \mathrm{~g} / \mathrm{cm}^{3}$ in full fat flours and 0.72 to $0.88 \mathrm{~g} / \mathrm{cm}^{3}$ in deffated flours. High bulk density of the groundnut accessions despite high oil content indicates that they would serve as good thickeners in food products.

\section{Conclusion}

Investigations carried out on the ten undefatted samples revealed that the carbohydrate, fat, protein and fiber content of improved accessions are significantly high. The high protein content of all accessions shows they could be a valuable protein supplement for cereals based food products. The high energy values obtained makes the accessions a very good energy store that can be utilized in the development of rich energy foods making it a possible means to manage protein-energy malnutrition.

Undefatted groundnut powder showed very good foaming stability. This would be suitable for use in food formulations where foaming is highly desired. The samples showed very good swelling power and solubility index indicating how readily the flour constituents would behave (reorient) under elevated temperature conditions. Despite the above, foaming capacity, water absorption capacity and bulk density of the samples were affected by the high fat content.

It is recommended that where functional properties are desired a fair reduction of fat in groundnut samples should be investigated to ascertain the level of fat that would allow for excellent functional properties.

\section{Acknowledgements}

The authors are grateful to Alliance for Green Revolution in Africa (AGRA) for providing the funds and CSIR-CRI for providing the seeds.

\section{References}

[1] Awuah, R. T. (2000) Aflatoxigenic fungi and aflatoxin contamination of groundnut based products in Ghana: Implications and concerns. In: R T Awuah and W O Ellis (eds): Proceedings of the National Workshop on Groundnut and Groundnut Aflatoxins. 19-21 September, 1999, Santasi-Kumasi, Ghana. pp 17-26.

[2] Tshilenge-Lukanda L, Nkongolo K. K. C, Narendrula R, KalonjiMbuyi A, Kizungu R. V (2012). Molecular characterization of groundnut (ArachishypogaeaL.) accessions from a gene pool: Application of gamma ray radiations" Journal of Plant Breeding and Crop Science Vol. 4(11). pp. 175-183.

[3] NARP (1993). National Agricultural Research Projects Report. Grain Legumes, Accra, Ghana: NARP.

[4] MOFA, (2010). Agriculture in Ghana; Facts and Figures" Statistics Research and Information Department 3-10, 42-48.

[5] Angelucci F and Bazzucchi A (2013). Analysis of incentives and disincentives for groundnuts in Ghana. Technical notes series, MAFAP, FAO, Rome

[6] Atasie V.N, Akinhanmi T.F and Ojiodu C.C (2009). "Proximate analysis and Physico-Chemical Properties of Groundnut (Arachis Hypogea L.)". Pakistan Journal of Nutrition, 8(2): 194-197.

[7] AOAC, Official Methods of Analysis of AOAC International, 16th edition, Association of Official Analytical Chemists, Washington, DC, 1997.

[8] Leach, H.W., Mc Cowen D.L. and Schoch, T.J. (1959). Swelling and Solubility Patterns of various starch. Structure of Starch Granule".Cereal Chem., 36: 534-544.

[9] Sathe, S.K., Salunkhe, D.K. (1981). Functional properties of great northern bean (Phaseolus vulgaris) proteins: Emulsion, foaming, viscosity and gelation properties. J. Food Sci. 46: 71-75.

[10] Adebowale A. A, Sanni L. O. and Awonorin S. O. (2005). Effect of texture modifiers on the physicochemical and sensory properties of dried fufu. .Food Sci. Technol. Intl. 1(5): 373-382.

[11] Jitngarmkusol, S., Hongsuwankul, J. and Tananuwong, K., (2008). Chemical compositions, functional properties, and microstructure of defatted macadamia flours, Food Chemistry, 110: 23-30.

[12] Maninder, K., Kawaljit, S.S., and Narpinder, S., (2007). Comparative study of the functional, thermal and pasting properties of flours from different field pea (Pisum sativum L.) and pigeon pea (Cajanus cajan L.) cultivars, Food Chemistry, 104, 259-267.

[13] Ayoola P.B. and Adeyeye, A, (2010). Effect of Heating on the Chemical Composition and Physico - Chemical Properties of Arachis hypogea (Groundnut) Seed Flour and Oil" Pakistan Journal of Nutrition, 9 (8): 751-754, 2010

[14] Ingale, S. and Shrivastava, S. K (2011). Nutritional study of new variety of groundnut (ArachishypogaeaL.) JL-24 seeds. African Journal of Food Science, 5(8), pp. 490-498.

[15] Gul, S. and Safdar, M. (2009). Proximate Composition and Mineral Analysis of Cinnamon. Pakistan Journal of Nutrition, 8 (9): 1456-1460.

[16] Eshun G, Amankwah A. E. and Barimah, J. (2013). Nutrients content and lipid characterization of seed pastes of four selected peanut (Arachis hypogaea) varieties from Ghana. African Journal of Food Science, 7(10), pp. 375-381.

[17] Graham D.E. and Phillips MC (1976). Foams. Academic Press, London. p. 237.

[18] Fekria, A. M., Isam, A. M. A., Suha, O. A. and Elfadil, E. B. (2012). Nutritional and functional characterization of defatted seed cake flour of two Sudanese groundnut (Arachishypogaea) cultivars. International Food Research Journal 19(2): 629-637.

[19] Yu, J., Liu, Y.F., Qiu, A.Y. and Wang, X.G. (2007). Preparation of isoflavones enriched soy protein isolate from defatted soy hypocotyls by supercritical $\mathrm{CO}_{2}$. Lwt- J Food Sci. Tech. 40: 800-806.

[20] Ikegwu, O.J., Okechukwu, P.E. and Ekumankana E.O. (2010) "Physico-Chemical and Pasting Characteristics of Flour and Starch from Achi (Brachystegia eurycoma) Seed. Journal of Food Technology, 8(2): 58-66.

[21] Dengate, H.W. (1984). Swelling, Pasting and Gelling of Wheat Starch" In: Pomeranz, Y(Ed). Advances in Cereal Science and Technology. America Association of Cereal Chemist (AACC) St. Paul, MN, pp: 49-71. 